\title{
Rapid Determination of Carbendazim Residues in Mushrooms by Immunosorbent Assay ${ }^{1}$
}

\author{
Yang Song ${ }^{1}$, Chun-hua Xie ${ }^{1}$, Min-si Wang ${ }^{1}$, Shuang Liu ${ }^{1}$, Zhi-jun Zhang ${ }^{2}$ and Yong-bin Zhou *, 3 \\ ${ }^{1}$ Tianjin Key Laboratory of Animal and Plant Resistance, College of Life Sciences, Tianjin Normal University, Tianjin 300387, China; \\ 2. National Engineering and Technology Research Center for Preservation of Agricultural Products, Tianjin Key Laboratory of Postharvest \\ Physiology and Storage of Agricultural Products, Tianjin 300384, China ; \\ 3. Tianjin Forestry and Fruit Research Institute, 300384.
}

\begin{abstract}
In this study, the testing time was reduced to $1 \mathrm{~h}$ through optimizing, and an LOD of $0.3 \pm 0.15$ $\mu \mathrm{g} \cdot \mathrm{L}^{-1}$ and an $\mathrm{IC}_{50}$ of $2.7 \pm 0.3 \mu \mathrm{g} \cdot \mathrm{L}^{-1}$ were achieved by the optimized CD-ELISA. The sample extraction of 1 -fold acetonitrile followed by a 20 -fold dilution in assay diluted buffer has proven to be sufficient to eliminate the influence of matrix. The CD-ELISA was validated further by comparing with the standard HPLC. The average recovery ratio of $89.7 \% \sim 112.7 \%$ was obtained, and the coefficients of variation were less than $11.0 \%$. In actual samples detection, except for Pleurotus eryngii, carbendazim was not detected, and other mushrooms were all detected, and only carbendazim in Volvariella volvacea exceeded the standard, and the over-standard rate was $16.7 \%$. In a word, the rapid, sensitive and efficient CD-ELISA for quantifing carbendazim in mushrooms was established in the study.
\end{abstract}

\section{INTRODUCTION}

As a broad spectrum benzimidazole fungicide, carbendazim is widely used in agricultural production with the characteristics of high efficiency, low toxicity and the inner attraction ${ }^{[1]}$. In addition to being applied to a wide range of cereals, fruits, vegetables, field crops etc, the carbendazim also was, until recently, routinely recommended for the control of cobweb disease of mushrooms ${ }^{[2]}$. The study found carbendazim had certain teratogenic effect, and was very stable in soil and water and difficult to decompose ${ }^{[3]}$. In 2011, the United States environmental protection agency (EPA) had limited the amount of carbendazim in orange juice to $100 \mu \mathrm{g} \cdot \mathrm{L}^{-1}, 200$ $\mu \mathrm{g} \cdot \mathrm{L}^{-1}$ was allowed in the EU, and the amount was not more than $3 \mathrm{mg} \cdot \mathrm{L}^{-1}$ for Japan ${ }^{[4]}$. The EU allowed the MRLS of carbendazim in fresh mushrooms to be 0.1 $\mathrm{mg} \cdot \mathrm{L}^{-1}$, the MRLS in the edible fungus is $1 \mathrm{mg} \cdot \mathrm{L}^{-1}$ in Korea, Britain and China, and $3 \mathrm{mg} \cdot \mathrm{L}^{-1}$ is for Japan ${ }^{[5]}$.

In recent years, some immunochemical methods ${ }^{[6]}$, such as enzyme linked immunosorbent assay (ELISA) ${ }^{[7-8]}$ or Surface Plasmon Resonance(SPR) were widely used. Some sensitive and selective ELISAs for quantifing carbendazim in fruits and vegetables had been set up and applied $^{[9-10]}$. In 2018, Guo, Linglinget al ${ }^{[11]}$ had proposed a method based on the inhibition of plant esterase from pesticides and validated for the determination of carbendazim residues in aqueous samples. After optimization in $\mathrm{pH}$, temperature, and detectiontime, a lower detection limit of $0.105 \mathrm{mu} \mathrm{M}$ was obtained in the linear range from 0.105 to $41.84 \mathrm{mu}$ M. In 2015, Ana $\mathrm{Ucl}^{\prime}$ es et $\mathrm{al}^{[12]}$ had established an ELISA for detecting carbendazim, imazalil and thiabendazole residues in vegetable samples, and through $2 \mathrm{~h}^{\prime}$ testing, the $0.5 \mu \mathrm{g} \cdot \mathrm{kg}^{-}$ ${ }^{1} \sim 13.8 \mu \mathrm{g} \cdot \mathrm{kg}^{-1}$ of IC 50 value of the calibration curve was obtained, after simple pretreatment, the method has a linearity range of $10 \mu \mathrm{g} \cdot \mathrm{kg}^{-1} \sim 80 \mu \mathrm{g} \cdot \mathrm{kg}$. Above these researches, complex pretreatment method can't meet the needs of the rapid detection.

In the study, to develop a repid and sensitive ELISA for the carbendazim in mushrooms, some research carried out were as follows: the direct competitive ELISA(CDELISA) for detecting carbendazim was established with simple sample extraction and fast determination only costing $1 \mathrm{~h}$ after optimizing experiments. The CD-ELISA could be applied to the rapid quantitative determination of carbendazim in food, especially in mushrooms.

\section{EXPERIMENTAL}

\subsection{Chemical and Reagents}

Carbendazim, benomyl, thiophanate, thiophanatem -ethyl, thiabendazole, 2-aminobenzimidazole, metat -olyl-Nmethylcarbamate were obtained from Toronto Research Chemicals INC(TRC, Canada). 3,3',5,5'-tetramethyl-

*Corresponding author:*Zhou Yong-bin: 2438059329@qq.com 
benzidine (TMB) and hydrogen peroxide were obtained from Sigma Chemical Co. (St. Louis, MO). Bovine serum albumin (BSA) was obtained from Merck (Darmstadt, Germany). Protein A-Sepharose 4B was purchased from GE. Carbendazim antibody was from the laboratory.

\subsection{Buffers and Solutions}

Phosphate-buffered saline (PBS), phosphate buffered saline with $0.05 \%$ Tween-20 (PBST), assay diluted buffer(PBSB, PBS $+0.1 \%$ BSA), coating buffer, blocking buffer, TMB substra -te solution, and stopping solution were used.

Stock standard solutions $\left(1 \mathrm{mg} \cdot \mathrm{mL}^{-1}\right)$ of all pesticides were prepared by dissolving in methanol. The individual stock solutions were stored away from light at $-20^{\circ} \mathrm{C}$ in brown glass bottles.

\subsection{Instrumentation}

ELISA experiments were performed in 96-well microplates (Nunc, Roskilde, Denmark), a microplate washer was from Bio-Rad (Hercules, CA) and the absorbances were read with a Multiskan Spectrum from Thermo (Labsystems, Vantaa, Finland) in dualwavelength mode $(450 \mathrm{~nm}$ and $650 \mathrm{~nm})$.

\subsection{Preparation of Protein Conjugates}

The immunogen, coating antigen and enzyme conjugate were prepared by conjugating the SBI to OVA and POD respectively by the active ester method described by Wang et al ${ }^{[13]}$.

\subsection{Direct ELISA}

Polystyrene ELISA plates were coated with purified antibodies in $100 \mu \mathrm{L}$ of $\mathrm{CB}$ and incubated for $3 \mathrm{~h}$ at $37^{\circ} \mathrm{C}$. Plates were then washed three times with $10 \mathrm{mmol} \cdot \mathrm{L}^{-1}$ of PBST, and unbound active sites were blocked with $200 \mu \mathrm{L}$ of $0.5 \%$ skim milk power per well for $1 \mathrm{~h}$. After the plate had been washed four times, competitive assays were performed by adding respectively $50 \mu \mathrm{L}$ of standard or samples and $50 \mu \mathrm{L}$ of SBI-POD conjugate diluted in PBS to each well and incubating for $1 \mathrm{~h}$ at room temperature. After washings of five times, $150 \mu \mathrm{L}$ of TMB substrate solution was added to each well. And the enzymatic reaction was stopped after $15 \mathrm{~min}$ by adding $50 \mu \mathrm{L}$ of 1.25 $\mathrm{mol} \cdot \mathrm{L}^{-1} \mathrm{H}_{2} \mathrm{SO}_{4}$ per well, and the absorbance was read in the micro-plate reader in dual wavelength mode $(450 \mathrm{~nm}$ as test and $650 \mathrm{~nm}$ as reference).

\subsection{Assay Specificity}

The carbendazim and its structural analogs were detected by an optimized ELISA method, and the inhibition curve was drawn to obtain the corresponding $\mathrm{IC}_{50}$ value, and the cross reaction was calculated. Cross-reactivity (CR) was calculated as follows:

$$
\begin{gathered}
\mathrm{CR}=\left[\mathrm{IC}_{50}(\text { carbendazim }) / \mathrm{IC}_{50} \text { (compound) }\right] \\
\times 100 \cdots \cdots \cdots \cdots \cdots \cdots \cdots \cdots
\end{gathered}
$$

\subsection{Sample Preparation}

Five different mushroom matrices: selection of shiitake, Agaricus bisporus, Pleurotus eryngii, Pleurotus and Volvariella volvacea (Bull.:Fr.) Sing to assess the accuracy of the CD-ELISA method, all samples from different markets. Each sample tested was determined to contain no carbendazim by HPLC prior to the spike recovery experiment. Firstly, the edible raw portion from the individual samples was minced to fine pieces by the food processor, then which were instantly freezed and stored at $-20^{\circ} \mathrm{C}$ until used.

\subsection{Sample Extraction}

For ELISA: $1 \mathrm{~g}$ of samples were spiked with carbendazim (except blank samples), and standed $30 \mathrm{~min}$ at room temperature, then $1 \mathrm{~mL}$ of acetic acid/acetonitrile (1:99, $\mathrm{v} / \mathrm{v}$ ) plus $0.4 \mathrm{~g}$ anhydrous $\mathrm{Na}_{2} \mathrm{SO}_{4}$ and $0.05 \mathrm{~g} \mathrm{NaAc}$ were added acetonitrile was added and vortexed for $2 \mathrm{~min}$. The mixture was centrifuged at $6000 \mathrm{rpm}$ for $3 \mathrm{~min}$, and the clear supernatant was collected and stored at $-20^{\circ} \mathrm{C}$, and diluted appropriately with buffer before ELISA analysis.

For HPLC: To validate the ELISA method, samples were analyzed by HPLC for comparison. The way of sample extraction was same as the report by Guo B et al ${ }^{[14]}$.

\subsection{HPLC Determination}

HPLC determination was performed by Agilent 1200 series.Operating conditions were as follows: injection volume, $20 \mathrm{uL}$; flow-rate, $1.0 \mathrm{ml} / \mathrm{min}$; test wavelength, $286 \mathrm{~nm}$; the mobile phase, methanol/water $(1: 1, \mathrm{v} / \mathrm{v})$.

\section{RESULTS AND DISCUSSION}

\subsection{Optimization of working conditions}

To establish working curve of CD-ELISA, some relevant reaction conditions such as ionic strength and organic solvent were optimized. A checkerboard method was used for optimization to get the lowest $\mathrm{IC}_{50}$ and maximum absorbance value ranging from 0.8 to $1.2^{[15]}$. The results show that $\mathrm{A}^{0} / \mathrm{IC}_{50}$ at $\mathrm{pH} 7.4$ is good.

The effect of acetonitrile concentration from $2.5 \%$ to $15 \%$ $(\mathrm{v} / \mathrm{v})$ on immunoassay performance was investigated. Figure 1 showed that acetonitrile could change the sensitivity of the assay. When the acetonitrile concentration was more than $5 \%$, the detection sensitivity was lowered.

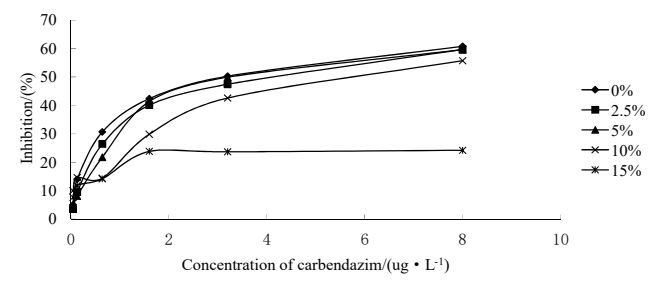

Fig.1. The effect of acetonitrile content in ELISA

The blocked and reaction time were optimized. No antibody was coated on plate to evaluate the effect. As 
shown in table 1, the blocked assay had no influence on $\mathrm{IC}_{50}$ or absorbance value. So the blocked assay can be omitted in the study. Secondly, when the time of the competitive assays reached $45 \mathrm{~min}$ the absorbance value raised to about $0.85 \mathrm{~A}$ and kept stand, however, the $\mathrm{IC}_{50}$ also enlarged to about $2.8 \mu \mathrm{g} \cdot \mathrm{L}-1$. Thus, to obtain less $\mathrm{IC}_{50}$, $30 \mathrm{~min}$ of the competitive assays were appropriate.

Tab.1. The optimization of time of competitive assays and blocked

\begin{tabular}{ccccc}
\hline Compe & \multicolumn{2}{c}{0 min } & \multicolumn{2}{c}{$15 \mathrm{~min}$} \\
\cline { 2 - 5 } $\begin{array}{c}\text { titive } \\
\text { Assays } \\
(\min )\end{array}$ & $\mathrm{A}^{0}(\mathrm{~A})$ & $\begin{array}{c}\mathrm{IC}_{50} \\
\left(\mu \mathrm{g} \cdot \mathrm{L}^{-}\right.\end{array}$ & $\mathrm{A}^{0}(\mathrm{~A})$ & $\begin{array}{c}\mathrm{IC}_{50} \\
\left(\mu \mathrm{g} \cdot \mathrm{L}^{-}\right. \\
1\end{array}$ \\
\hline 15 & 0.52 & 1.7 & 0.50 & 1.5 \\
30 & 0.73 & 1.8 & 0.80 & 1.7 \\
45 & 0.85 & 2.8 & 0.84 & 2.7 \\
60 & 0.84 & 2.9 & 0.86 & 3.0 \\
\hline
\end{tabular}

Note: The time of blocked were $0 \mathrm{~min}$ and $15 \mathrm{~min}$; the time of competitive assays were 15, 30, 45, $60 \mathrm{~min}$.

\subsection{LOD and working range}

The working curves of carbendazim were set up by optimizing the conditions related to CD-ELISA, as shown in Figure 2. The detailed conditions were as follows: coating antibody dose and enzyme conjugate dilution factors were $5 \mu \mathrm{g} \cdot \mathrm{mL}^{-1}$ and 150-fold (diluted with PBS); the blocked was left out, adding 45 min of competitive assays, so only $1 \mathrm{~h}$ of the total reaction time was needed; Working standard solution of carbendazim was prepared by diluting the stock standard solution in Buffer (PBS + $0.5 \%$ Tween-20) and was stored at $4^{\circ} \mathrm{C}$. The linear working range was $0.4 \mu \mathrm{g} \cdot \mathrm{L}^{-1} \sim 58.0 \mu \mathrm{g} \cdot \mathrm{L}^{-1}$, which is determined as the concentration causing $20-80 \%$ inhibition of color development ${ }^{[8]}$, and $\mathrm{IC}_{15}$ and $\mathrm{IC}_{50}$ were $0.3 \pm 0.15 \mu \mathrm{g} \cdot \mathrm{L}^{-1}$ and $2.7 \pm 0.3 \mu \mathrm{g} \cdot \mathrm{L}^{-1}$, respectively.

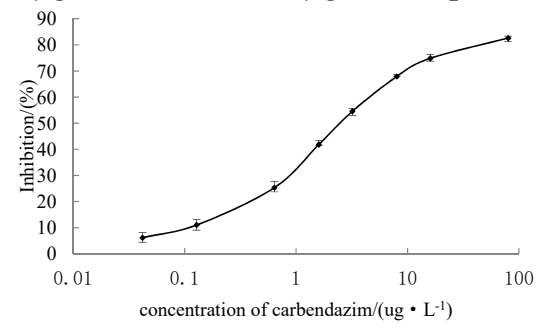

Fig.2. The standard curves of carbendazim in CD-ELISA

\subsection{Assay Specificity}

The cross reactivity of a set of analogs was determined using the optimized CD-ELISA system. (Tab.2.). From Table 2, we found that the antibody was specific to carbendazim highly. And because the active components of benomyl just was carbendazim.

Tab.2. The $\mathrm{IC}_{50}$ and $\mathrm{CR}$ of compounds

\begin{tabular}{|c|c|c|c|c|c|}
\hline $\begin{array}{c}\text { compou } \\
\text { nds }\end{array}$ & $\begin{array}{c}\mathrm{IC}_{50}(\mu \mathrm{g} \\
\left.\cdot \mathrm{L}^{-1}\right) \\
\end{array}$ & $\begin{array}{c}\mathrm{CR}( \\
\%)\end{array}$ & compounds & $\begin{array}{c}\mathrm{IC}_{50}(\mu \mathrm{g} \\
\left.\cdot \mathrm{L}^{-1}\right) \\
\end{array}$ & $\begin{array}{l}\mathrm{CR}( \\
\%)\end{array}$ \\
\hline $\begin{array}{c}\text { Carbend } \\
\text { azim }\end{array}$ & 2.5 & 100 & $\begin{array}{c}2- \\
\text { Aminobenzimi } \\
\text { dazole }\end{array}$ & 1200 & 0.2 \\
\hline $\begin{array}{c}\text { Benomy } \\
1\end{array}$ & 4.0 & 62.5 & Thiabendazole & 1800 & 0.1 \\
\hline $\begin{array}{l}\text { Thiopha } \\
\text { nate }\end{array}$ & 71 & 3.5 & $\begin{array}{c}\text { Thiophanate } \\
\text { methyl }\end{array}$ & 150 & 1.7 \\
\hline
\end{tabular}

\begin{tabular}{cll}
\hline $\begin{array}{c}\text { Metolca } \\
\mathrm{rb}\end{array}$ & $\mathrm{n}$ & 0 \\
\hline
\end{tabular}

\subsection{Matrix effects and their removal}

Matrix effects can induce some influence on the antigenantibody interaction and enzymatic activity, and also lead to false positives. Bigger dilution ratio means smaller the influence of the matrix, but in consideration of LOD(limit of detection) of samples and sensitivity of the ELISA, smaller dilution ratio was needed. Some masking agent (BSA) or surfactant (Tween-20) was used to increase sensitivity.

As shown in Table 3 and 4, when the percentage of $\mathrm{BSA}$ raised to $0.1 \%$ the absorbance value $(0.73 \mathrm{~A})$ and the $\mathrm{IC}_{50}\left(2.1 \mu \mathrm{g} \cdot \mathrm{L}^{-1}\right)$ would not reduce and remain, $0.1 \%$ of BSA could eliminate the impact of non-specific binding. Thus, if the matrix was diluted with PBSB, the diluted ratio of matrix would be reduced from 40 -fold to 20 -fold. And the $\mathrm{IC}_{15}$ and $\mathrm{IC}_{50}$ of the standard curves(PBS+0.5\% Tween-20) were $0.3 \mu \mathrm{g} \cdot \mathrm{L}^{-1}$ and $3.0 \mu \mathrm{g} \cdot \mathrm{L}^{-1}$, so the limit of detection and sensitivity of the way was $6 \mu \mathrm{g} \cdot \mathrm{L}^{-1}$ and 60 $\mu \mathrm{g} \cdot \mathrm{L}^{-1}$.

Tab.3. The influence of content of BSA and Tween-

\begin{tabular}{cccccccc}
\multicolumn{8}{c}{20 on standard curves (PBS) } \\
\hline Buffer & PBS & \multicolumn{7}{c}{ BSA } & & & Tween-20 \\
& & 0.01 & 0.1 & $1 \%$ & 0.00 & 0.05 & 0.5 \\
& & $\%$ & $\%$ & & $5 \%$ & $\%$ & $\%$ \\
\hline $\begin{array}{c}\mathrm{IC}_{50}(\mu \mathrm{g} \cdot \\
\left.\mathrm{L}^{-1}\right) \\
\mathrm{A}_{0}(\mathrm{~A})\end{array}$ & 2.5 & 2.4 & 2.1 & 1.9 & 2.5 & 2.6 & 3.0 \\
& 0.86 & 0.80 & 0.73 & 0.73 & 0.71 & 0.6 & 0.51 \\
\hline
\end{tabular}

Tab.4. The comparation of different sample pretreatment

\begin{tabular}{ccccc}
\hline way & $\mathrm{IC}_{15}\left(\mu \mathrm{g} \cdot \mathrm{L}^{-1}\right)$ & $\mathrm{IC}_{50}\left(\mu \mathrm{g} \cdot \mathrm{L}^{-1}\right)$ & $\mathrm{LOD}\left(\mu \mathrm{g} \cdot \mathrm{L}^{-1}\right)$ & Sensitivity $\left(\mu \mathrm{g} \cdot \mathrm{L}^{-1}\right)$ \\
\hline $\mathrm{A}$ & 0.4 & 2.6 & 16 & 104 \\
$\mathrm{~B}$ & 0.3 & 3.0 & 6 & 60 \\
\hline
\end{tabular}

Note: A: standard curves(PBST), matrix curves (40-fold, with PBS); B: standard curves(PBS $+0.5 \%$ Tween-20), matrix curves(20-fold, with PBS+0.1\%BSA).

In the study, standard curve was prepared in PBS with different ratios of the Shiitake extract. As shown in Figure 3 , the different percentage of the matrix also had different levels of impact on the sensitivity (5\% and 10\%). When the percentage was $2.5 \%$ the similar $\mathrm{IC}_{15}$ and $\mathrm{IC}_{50}$ were showed in matrix calibration curves and the standard curves, thus, extracts should be diluted at least 40 -fold before analyzed accurately.
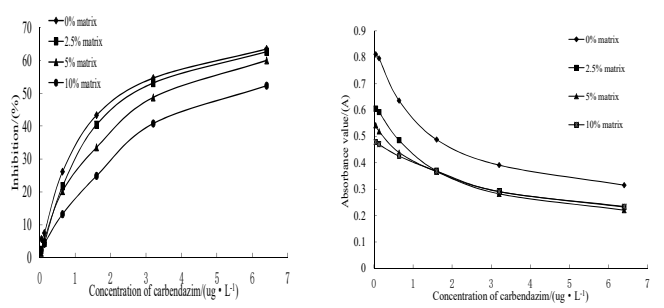

Fig. 3. The effect of matrix on inhibition curve and Absorbance curve

At the same time, a significant effect on the absorbance value could be observed when the matrix was added to the 
buffer $(2.5 \%, 5 \%$ and $10 \%)$, and even the matrix was diluted 40-fold, its absorbance value still was much less than the standard curves'(PBS). From Figure 4 and Table 3 , only the percentage of Tween-20 was less than $0.005 \%$, the Tween-20 could reduce the non-specific binding without affecting the sensitivity, and when the content of Tween-20 between $0.005 \%$ and $0.05 \%$ it had small impact on the sensitivity. As shown in Figure 4, the absorbance value decreased with the Tween-20 increasing. Thus, when the standard curves was prepared with PBST the absorbance value and inhibition of standard curves and matrix curves(40-fold,with PBS) were almost the same.
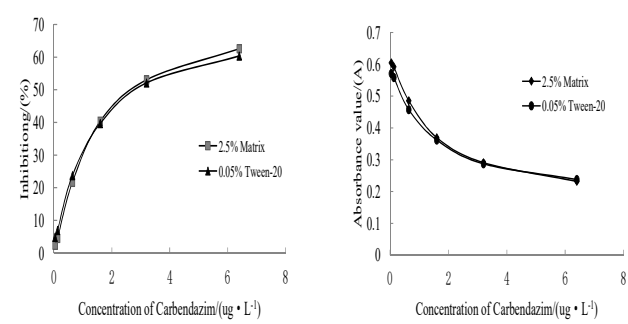

Fig.4. The comparation between the standard curves $(0.05 \%$ Tween- 20$)$ and the matrixcurves (2.5\%Matrix).

\subsection{Recovery studies}

In order to demonstrate accuracy and efficiency of the CDELISA, the recovery experiment by adding three-level standard samples, was carried out, as shown in Table 5, the average recovery ratio were $89.7 \% \sim 112.7 \%$, despite this slight overestimation or underestimation, which is found within the range accepted in an analytical methodology, and all of coefficients of variation (CV) were less than $11.0 \%$, which indicated the developed sample extraction and the CD-ELISA of detecting carbendazim in food samples could be applied.

Tab.5. The recovery ratio of five mushrooms at three levels by CD-ELISA(n=3)

\begin{tabular}{ccccc}
\hline \multirow{2}{*}{ sample $(\mathrm{n}=3)$} & $\begin{array}{c}\text { Spiked level } \\
\left(\mu \mathrm{g} \cdot \mathrm{L}^{-1}\right)\end{array}$ & $\begin{array}{c}\text { Mean } \pm \text { SD }\left(\mu \mathrm{g} \cdot \mathrm{L}^{-}\right. \\
1)\end{array}$ & Recovery $(\%)$ & CV (\%) \\
\hline \multirow{2}{*}{ Shiitake } & 10 & $9.7 \pm 1.1$ & 97.0 & 11.0 \\
& 20 & $18.1 \pm 1.7$ & 89.7 & 9.1 \\
Pleurotus eryngii & 40 & $41.3 \pm 2.1$ & 103.2 & 4.2 \\
& 10 & $11.3 \pm 0.9$ & 112.7 & 6.4 \\
Agaricus bisporus & 20 & $20.8 \pm 1.5$ & 104.0 & 5.3 \\
& 40 & $38.2 \pm 3.6$ & 95.5 & 8.8 \\
& 10 & $9.3 \pm 0.6$ & 93.0 & 4.3 \\
Pleurotus & 20 & $22.3 \pm 2.0$ & 111.5 & 9.3 \\
& 40 & $38.3 \pm 3.2$ & 95.8 & 7.4 \\
Volvariella volvacea & 10 & $9.2 \pm 0.7$ & 92.0 & 4.5 \\
(Bull.:Fr.) Sing. & 20 & $19.3 \pm 2.6$ & 96.5 & 3.2 \\
& 40 & $40.2 \pm 0.5$ & 100.5 & 6.3 \\
& 40 & $9.5 \pm 1.4$ & 95.0 & 10.2 \\
& 10 & $19.8 \pm 1.3$ & 99.0 & 5.5 \\
\hline
\end{tabular}

Note: All of the sample extraction were diluted 20-fold with the solution(PBS $+0.1 \%$ BSA) before analyzed.

Then the CD-ELISA was validated further by comparing with the standard HPLC, two different samples that did't contain carbendazim and benomyl were added respectively standard at three levels $\left(10 \mu \mathrm{g} \bullet \mathrm{kg}^{-1}, 20 \mu \mathrm{g} \bullet \mathrm{kg}^{-}\right.$ 1, $\left.40 \mu \mathrm{g} \bullet \mathrm{kg}^{-1}\right)$, then extracted by their method, and analyzed simultaneously through the HPLC and the CDELISA. The monitoring results of same matrix of two methods of were linear. And the correlation coefficient $\left(\mathrm{R}^{2}\right)$ of HPLC and CD-ELISA was 0.9822, indicating two methods had high consistency.
Five mushrooms were purchased from six different markets and carbendazim was detected by established CDELISA and HPLC methods, respectively. As shown in Table 6 except for the carbendazim that was not detected by Pleurotus eryngii, other mushrooms were all detected, and only the carbendazim in Volvariella volvacea exceeded the standard, and the over-standard rate was $16.7 \%$. At the same time, the detection result of CDELISA is consistent with the detection result of HPLC.

\subsection{Actual sample test results}


Tab.6. detection of carbendazim in actual samples $(n=3)$

\begin{tabular}{|c|c|c|c|c|c|c|c|}
\hline \multirow[b]{2}{*}{$\begin{array}{c}\text { Sample } \\
(\mathrm{n}=3)\end{array}$} & \multirow[b]{2}{*}{ number } & \multicolumn{3}{|c|}{ CD-ELISA } & \multicolumn{3}{|c|}{ HPLC } \\
\hline & & $\begin{array}{c}\text { Carbendazim } \\
\text { residue } \\
(\mu \mathrm{g} / \mathrm{kg})\end{array}$ & $\begin{array}{l}\text { detection } \\
\text { rate }(\%)\end{array}$ & $\begin{array}{l}\text { excess } \\
\text { rate } \\
(\%)\end{array}$ & $\begin{array}{c}\text { Carbendazim } \\
\text { residue } \\
(\mu \mathrm{g} / \mathrm{kg})\end{array}$ & $\begin{array}{c}\text { detection } \\
\text { rate }(\%)\end{array}$ & $\begin{array}{l}\text { excess } \\
\text { rate }(\%)\end{array}$ \\
\hline \multirow{5}{*}{ Shiitake } & 1 & $32.3 \pm 1.4$ & \multirow{5}{*}{66.7} & \multirow{5}{*}{0} & $31.4 \pm 1.2$ & \multirow{5}{*}{66.7} & \multirow{5}{*}{0} \\
\hline & 2 & $21.2 \pm 3.1$ & & & $20.3 \pm 2.8$ & & \\
\hline & 3 & $18.3 \pm 0.3$ & & & $18.1 \pm 0.3$ & & \\
\hline & 4 & $41.3 \pm 0.6$ & & & $40.3 \pm 0.7$ & & \\
\hline & $5-6$ & - & & & - & & \\
\hline $\begin{array}{l}\text { Pleurotus } \\
\text { eryngii }\end{array}$ & $1-6$ & - & 0 & 0 & - & 0 & 0 \\
\hline \multirow{6}{*}{$\begin{array}{l}\text { Agaricus } \\
\text { bisporus }\end{array}$} & 1 & $53.2 \pm 0.6$ & \multirow{6}{*}{83.3} & & $51.4 \pm 0.8$ & \multirow{6}{*}{83.3} & \multirow{6}{*}{0} \\
\hline & 2 & $51.3 \pm 2.1$ & & & $50.8 \pm 2.3$ & & \\
\hline & 3 & $61.3 \pm 1.8$ & & , & $63.2 \pm 1.3$ & & \\
\hline & 4 & $50.8 \pm 0.7$ & & 0 & $52.1 \pm 1.2$ & & \\
\hline & 5 & $72.4 \pm 0.9$ & & & $71.8 \pm 2.6$ & & \\
\hline & 6 & - & & & - & & \\
\hline \multirow{3}{*}{ Pleurotus } & 1 & $69.2 \pm 2.7$ & \multirow{3}{*}{33.3} & \multirow{3}{*}{0} & $68.2 \pm 2.1$ & \multirow{3}{*}{33.3} & \multirow{3}{*}{0} \\
\hline & 2 & $73.2 \pm 1.8$ & & & $72.9 \pm 1.4$ & & \\
\hline & $3-6$ & - & & & - & & \\
\hline \multirow{4}{*}{$\begin{array}{l}\text { Volvariella } \\
\text { volvacea }\end{array}$} & $1-3$ & $109.5 \pm 1.4$ & \multirow{4}{*}{50.0} & \multirow{4}{*}{16.7} & $108.3 \pm 1.6$ & \multirow{4}{*}{50.0} & \multirow{4}{*}{16.7} \\
\hline & 4 & - & & & - & & \\
\hline & 5 & $72.3 \pm 2.4$ & & & $71.8 \pm 3.0$ & & \\
\hline & 6 & $61.4 \pm 1.4$ & & & $60.9 \pm 1.1$ & & \\
\hline
\end{tabular}

Note:(-) means not detected.

\section{CONCLUSIONS}

In the study, a rapid and highly sensitive direct competitive ELISA immunoassay has been developed for detecting carbendazim in mushroom samples within $1 \mathrm{~h}$. The standard working curves of CD-ELISA was set up after lots of optimization with the linear working range of 0.4 $\mu \mathrm{g} \cdot \mathrm{L}^{-1} \sim 58.0 \mu \mathrm{g} \cdot \mathrm{L}^{-1}$, with the LOD of $0.3 \pm 0.15 \mu \mathrm{g} \cdot \mathrm{L}^{-1}$ and the $\mathrm{IC}_{50}$ of $2.7 \pm 0.3 \mu \mathrm{g} \cdot \mathrm{L}^{-1}$. The mushrooms were extracted with acetonitrile followed by dilution in buffer PBSB, which has been proven to be sufficient to eliminate the influence of matrix, and $89.7 \% \sim 112.7 \%$ of the average recovery ratio was gained. The new CD-ELISA was further verified by comparing with conventional HPLC, and the correlation coefficient $\left(\mathrm{R}_{2}\right)$ of 0.9822 showed high accuracy and efficiency of the CD-ELISA, coupled with the detection limit of $6 \mu \mathrm{g} \cdot \mathrm{L}^{-1}$, indicating the new CDELISA for rapid screening carbendazim in food could be applied widely.

\section{Funding}

This study was supported by National Natural Science Foundation [No. 31301487], Tianjin Natural Science Foundation (18JCQNJC84400) and Natural Science Foundation of Tianjin [13JCQNJC14800].

\section{REFERENCE}

1. Davidse LC. Benzimidazole fungicides: mechanism of action and biological impact. Annu Rev Phytopathol 24(1986): 43-65(2003).

2. Fletcher JT, White PF and Gaze RH. Mushrooms: Pest and disease control. 2nd edn, Intercept, Andover, Hants, UK (1989).

3. Huang YJ, Zhang XJ, Ren Y, Li JS, Zhang GZ and Yang HT. Isolation and identification of a carbendazim-degrading strain and its degrading characteristics. Shandong Sci 24: 28-34( 2011).

4. Li QP, Cui WH, Zheng M, Xiang LX, Guo Q, Jin J and Ha YM. Comparative analysis on domestic and foreign standards of pesticide carbendazim in juice. Journal of Food Safety \& Quality 4: 18921896( 2013).

5. $\mathrm{Wu} \mathrm{JM}$. The comparative analysis on domestic and foreign standards of pesticides in mushrooms. Edible Fungi 27: 3-5( 2005).

6. Amritkar RE and Jalan S. Development of competitive immunoassays to hydroxyl containing fungicide metabolites. Journal of Environmental Science and Health 46: 581-589( 2011).

7. Brandon DL, Binder RG, Bates AH, and Montague WC. Monoclonal Antibody for Multiresidue ELISA of Benzimidazole Anthelmintics in Liver. Journal of 
Agricultural and Food Chemistry 42: 15881594(1994).

8. Itak JA, Selisker MY, Jourdan SW, Fleeker JR and Herzog DP. Determination of benomyl (as carbendazim) and carbendazim in water, soil, and fruit juice by a magnetic particle-based immunoassay. Journal of Agricultural and Food Chemistry 41: 2329-2332(1993).

9. Lissenmore L, Ripley BD, Kakuda Y and Stephenson GR. Sensitivity, Specificity, and Predictive Value for the Analysis of Benomyl, as Carbendazim, on FieldTreated Strawberries Using Different Enzyme Linked Immunosorbent Assay Test Kits. Journal of Environmental Science and Health, Part B 31: 871882(1996).

10. Dong, Liang; Ren, Yan; Li, Junjie; et, al. Detection of Carbendazim Residues in Aqueous Samples by Fluorescent Quenching of Plant Esterase.JOURNAL OF APPLIED SPECTROSCOPY, 85( 3): 535542(2018).

11. Uclés A, García AV, García MDG, Real AMA and Fernández-Alba AR. Benzimidazole and imidazole fungicide analysis in grape and wine samples using a competitive enzyme-linked immunosorbent assay. Analytical Methods 7:9158-9165( 2015).

12. Wang S, Allan RD, Skerritt JH and Kennedy IR. Development of a compound-specific ELISA for flufenoxuron and an improved class-specific assay for benzoylphenylurea insect growth regulators. Journal of Agriculture and Food Chemistry 47: 3416-3424(1999).

13. Song Y, Zhang Y, Wang S and Wang J. Determination of metolcarb residues by a biotin-streptavidinamplified enzyme-linked immunosorbent assay in vegetables and edible fungus. Food and Agricultural Immunology 27: 1-11(2015).

14. Guo B, Huang ZQ, Wang ML, Wang XY, Zhang Y, Chen B, Li YJ, Yan HF, Yao SZ. Simultaneous direct analysis of benzimidazole fungicides and relevant metabolites in agricultural products based on multifunction dispersive solid-phase extraction and liquid chromatography-mass spectrometry. Journal of Chromatography A 1217: 4796-4807(2010).

15. Jin RY, Gui WJ, Guo YR, Wang CM, Wu JX and Zhu GN. Comparison of monoclonal antibody-based ELISA for triazophos between the indirect and direct formats. Food and Agricultural Immunology 19: 4960(2008). 